\title{
Establishment and Characterization of a Testicular Cell Line from the Hali-Smooth Tongue Sole, Cynoglossus semilaevis
}

\author{
Bo Zhang ${ }^{1,2^{*}}$, Xianli Wang ${ }^{1 *}$, Zhenxia Sha1, Changgeng Yang ${ }^{1}$, Shanshan Liu ${ }^{1,2}$, Na Wang1, \\ Song-Lin Chen ${ }^{1 \otimes}$
}

1. Yellow Sea Fisheries Research Institute, Chinese Academy of Fisheries Sciences, Qingdao, China, 266071;

2. Shanghai Ocean University, College of Fisheries and Life Science, Shanghai, China,201306

* These authors contributed equally to the work.

$\triangle$ Corresponding author: Tel: 0086-532-85844606; Fax: 0086-532-85811514 Email: chensl@ysfri.ac.cn

() Ivyspring International Publisher. This is an open-access article distributed under the terms of the Creative Commons License (http://creativecommons.org/ licenses/by-nc-nd/3.0/). Reproduction is permitted for personal, noncommercial use, provided that the article is in whole, unmodified, and properly cited.

Received: 2011.01.01; Accepted: 2011.04.10; Published: 2011.04.15

\begin{abstract}
Spermatogenesis within the adult testis is an excellent system for studying stem cell renewal and differentiation, which is under the control of testicular somatic cells. In order to understanding spermatogenesis in the half-smooth tongue sole (Cynoglossus semilaevis) as a marine fish model of aquaculture importance, we established a cell line called CSGC from a juvenile gonad of this organism. CSGC is composed of fibroblast-like cells, retains a diploid karyotype of 42 chromosomes, lacks the heterogametic W chromosome, lacks a female specific marker and expresses the dmrt, a marker for testicular somatic cells. Therefore, CSGC appears to consist of testicular somatic cell cells. We show that this cell line is effective for infection by the turbot reddish body iridovirus and flounder lymphocystis disease virus as evidenced by the appearance of cytopathic effect and virus propagation in the virus-infected cells, and most convincingly, the observation of viral particles by electon microscopy, demonstrateing that CSGC is suitable to study interactions between virus and host cells. As a first fish testicular somatic cell line of the ZZ-ZW genetic sex determination system, CSGC will be a useful tool to study sex-related events and interactions between somatic cells and germ cells during spermatogenesis.
\end{abstract}

Key words: half-smooth tongue sole, Cynoglossus semilaevis; gonadal cell line, Karyotype, cytopathic effects, virus susceptibility

\section{Introduction}

Cell lines provide an important in vitro system for investigations in physiology, virology, toxicology, carcinogenesis and transgenics. So far, many cell lines from freshwater and marine fish species have been reported since the first fish cell line-RTG-2 (1-3). These cell lines have been developed from a broad range of tissues such as the fin, kidney, muscle, liver, and embryos (4-8). Gonadal cell lines have not or rarely been developed from marine fish species $(9,10)$.

Gonadal somatic cell lines are of significance to study how the somatic environment can control the self-renewal of germ stem cells and their differentiation into gametes, namely oogenesis in the ovary and spermatogenesis in the testis. Although in vitro spermatogenesis in mammals has so far ended up with the spermatid stage $(11,12)$, spermatogenesis in lower vertebrates can proceed fully in vitro. Specifically, sperm production in vitro has been reported in primary testicular cultures from several distantly related fish species. In the eel, all stages of spermato- 
genesis were established in organ culture of immature testes (13). In the medaka, fertile sperm were obtained during 10 days of primary cultures of spermatocytes at the meiotic prophase (14). In the zebrafish, dissociated testicular cells during 15 days of coculture on a feeder layer of Sertoli-like cells gave rise to fertile sperm (15). Remarkablely, Hong et al have found that spermatogonia from the medaka testis can develop into a stable stem cell line called SG3, which is capable of full recapitulation of spermatogenesis in vitro, including differentiation through meiosis to generate test-tube sperm (16). These results demonstrate that in fish, it is possible to establish germ cell cultures and all stages of spermatogenesis in vitro for test-tube sperma production and for the analysis of interactions between somatic cells and germ cells in these processes. To this end, the availability of various testicular cell lines will provide necessary tools. In addition, gonadal somatic cells are involved in the sex differentiation in germ cells and organisms $(17,18)$.

The half-smooth tongue sole (Cynoglossus semilaevis) has 42 chromosomes and the $\mathrm{ZW}$ sex-determining system (19). In this organism, several cell lines have been established from the heart and embryos $(20,21)$. The establishment of gonadal cell cultures will provide a potential material to study mechanisms underlying sex determination and sex-related gene expression and function. Here we report the establishment of a cell line from a gonadal cell line, called CSGC, from the testis of the half-smooth tongue sole, which appears to consist of somatic cells in morphology and gene expression. We tested its susceptibility to the flounder lymphocystis disease virus (LCDV) and turbot reddish body iridovirus (TRBIV).

\section{Materials and Methods}

\section{Primary cell culture and subculture}

A half-smooth tongue-sole weighing $500 \mathrm{~g}$ was obtained from the MingBo Fisheries Company in Laizhou, Shandong Province, China, and was disinfected with $75 \%$ ethanol. The gonad was taken and transferred to a dish, washed three times with phosphate-buffered saline (PBS) containing antibiotics (penicillin, $1000 \mathrm{IU} / \mathrm{ml}$; streptomycin, $1000 \mu \mathrm{g} / \mathrm{ml}$ ), and minced by scissors into small pieces $\left(1 \mathrm{~mm}^{3}\right)$, which were transferred into $25-\mathrm{cm}^{2}$ tissue culture flasks containing $3 \mathrm{ml}$ of MEM with $20 \%$ fetal bovine serum (FBS), $2 \mathrm{ng} \mathrm{ml}^{-1} \mathrm{bFGF}$ and $1000 \mathrm{U}$ of penicillin, $1000 \mathrm{U}$ of streptomycin. The primary cells were maintained at $24{ }^{\circ} \mathrm{C}$. After three days, $2 \mathrm{ml}$ of growth medium was added to the flasks. One half of the growth medium was changed every 3 days for first week. Monolayers of primary cells formed after two weeks of culture.

Primary cultures were dissociated by treatment with $0.25 \%$ trypsin-EDTA solution (Sigma) into single cells and transferred into another fresh $25 \mathrm{~cm}^{2}$ flask at a split ratio of 1:2. Dissociation was monitored under an inverted light microscope (Nikon TE2000-S) to ensure that cells had been released from the flask surface. Cells were initially maintained in MEM with $20 \%$ FBS. After 45 passages the concentration of FBS in MEM was reduced to $15 \%$. During the first 30 subcultures, a MEM medium containing 20\% FBS was used and the cells were split at a ratio of 1:2 every 5-7 days. From passage 30 onwards, the cells were subcultured every 3 or 4 days. To date, CSGC cell line has been subcultured for more than 55 passages.

\section{Effect of different temperature and FBS con- centration on cells growth}

To analyze the growth requirement of the CSGC cells, $2 \times 10^{5}$ cells at passage 35 were inoculated in three wells of 12-well plate with MEM containing 20\% FBS and incubated separately at $10^{\circ} \mathrm{C}, 20^{\circ} \mathrm{C}, 24{ }^{\circ} \mathrm{C}$ and $30^{\circ} \mathrm{C}$ for growth curve tests, respectively. Following $1-$ 4 days post inoculation, cells in one well of different temperature were trypsinized, and cell numbers were measured microscopically via a hemocytometer. The effect of FBS concentration on cell growth at $24^{\circ} \mathrm{C}$ was evaluated in 6-well microplates for CSGC. The cells were seeded and incubated in MEM containing 5, 15, 20 and $25 \% \mathrm{FBS}$ and incubated at $24^{\circ} \mathrm{C}$. The cells were collected every day for four days and counted for three times in triplicate.

\section{Cryopreservation and recovery of cells}

Cells at $\sim 90 \%$ confluence were used for cryostorage. Single cell suspension by trypsinization from each flask was collected in a $15 \mathrm{ml}$ centrifuge tube and centrifuged at $1200 \mathrm{~g}$ for $3 \mathrm{~min}$ (Avanti-26XP, Beckman, USA). The cell pellet was resuspended at a density of $5 \times 10^{6}$ cells $/ \mathrm{ml}$ in cold medium $\left(4^{\circ} \mathrm{C}\right)$ containing 20\% FBS, 10\% dimethyl sulfoxide (DMSO) and $70 \%$ MEM medium. Cells were dispensed into 1.8-ml sterile plastic vial, which were put in a Styrofoam box, incubated at $-80^{\circ} \mathrm{C}$ for 4 hours and transferred into liquid nitrogen for cryostorage. To re-initiate culture from frozen cells, the vial from liquid nitrogen was thawed at $40^{\circ} \mathrm{C}$ for $1 \mathrm{~min}$, and centrifuged at $1000 \mathrm{~g}$ for $4 \mathrm{~min}$. The cells were suspended in fresh MEM and seeded into a $25 \mathrm{~cm}^{2}$-cell culture flask.

\section{Chromosome analysis}

Chromosome preparation for CSGC cells was carried out as described with some modifications (22). In brief, the CSGC cells at passage 25, 35, 50 were in- 
oculated in $25 \mathrm{~cm}^{2}$ culture flasks and incubated at $24^{\circ} \mathrm{C}$ for $36 \mathrm{~h}$. Colchicine was added into the cells at $0.1 \mu \mathrm{g} / \mathrm{ml}$. After $4 \mathrm{~h}$ incubation, the cells were treated with $6 \mathrm{ml}$ of hypotonic solution of $0.075 \mathrm{M} \mathrm{KCl}$ for 30 $\mathrm{min}$, and then pre-fixed for $3 \mathrm{~min}$ by dropping $1 \mathrm{ml}$ of Carnoy's fixative (3:1 methanol:glacial acetic acid) into the above cell suspension. After 5 min centrifugation at $1200 \mathrm{~g}$, the cell pellets were fixed with cold Carnoy's for $30 \mathrm{~min}$. After centrifugation, cells were resuspended in $0.5 \mathrm{ml}$ Carnoy's fixative, dropped and dispersed by blowing on cold glass slides. After air-drying, the slides were stained with $10 \%$ Giemsa (in $10 \mathrm{mM}$ potassium phosphate, $\mathrm{pH}$ 6.8) for $30 \mathrm{~min}$. The slides were observed and photographed under Nikon Eclipse 80I fluorescence microscope.

\section{Sex genotyping of CSGC}

The genetic sex of CSGC was determined by the presence or absence of a female-specific marker developed in our lab (23). Briefly, based on sequences of the female-specific AFLP fragments, a pair of specific PCR primers382 (CseF382N1:5'ATTCACTGACCCCTGAGAGC-3'; CseF382C1: 5'-AACAACT CACACACGACAAATG-3') was designed. A PCR reaction system $(25 \mu \mathrm{l})$ consisted of $1 \mathrm{ul}$ of $10 \mathrm{pM}$ of each primer, $1 \mathrm{ul}$ of $2.5 \mathrm{mM}$ of four dNTP each, $1 \mathrm{U}$ of Taq polymerase (Promega, USA), $1.5 \mu$ of $25 \mathrm{mM} \mathrm{Mg}^{2}$, and 1 to $2.0 \mu \mathrm{l}$ of $75 \mathrm{ng} / \mu \mathrm{l}$ of DNA as template. DNA was extracted from one female and one male soles as well as from CSGC cells. PCR was run as follows: initial incubation at $95{ }^{\circ} \mathrm{C}$ for $5 \mathrm{~min}$, followed by 30 cycles of $95^{\circ} \mathrm{C}, 30 \mathrm{~s} ; 57^{\circ} \mathrm{C}, 30 \mathrm{~s}$; and 72 ${ }^{\circ} \mathrm{C}$, $60 \mathrm{~s}$, with a final extension of $5 \mathrm{~min}$ at $72{ }^{\circ} \mathrm{C}$. The PCR products of $2 \mu 1$ were resolved on $1.5 \%$ agarose gel with a DL2000 DNA marker.

\section{RT-PCR analysis of dmrt I expression in CSGC cells}

A pair of specific primer of sex related gene, double sex and mab-3-related transcription factor1 (Dmrt1) (Dmrt-fw: GTCGCTGTGACA AGTGTAACCTC; Dmrt1-rv: TGAGACATCTGCTG GTATTGCTG) was used for PCR reaction system (15 $\mu 1)$. Total RNA was extracted from CSGC cells according to the Trizol $\mathrm{R}$ protocols (Invitrogen, Carlsbad, CA, USA) and first strand cDNA synthesized by RT-PCR with M-MLV reverse transcriptase (Promega,USA) was taken as template. PCR was run as follows: initial incubation at $94^{\circ} \mathrm{C}$ for $5 \mathrm{~min}$, followed by 28 cycles of $94^{\circ} \mathrm{C}, 30 \mathrm{~s} ; 56^{\circ} \mathrm{C}, 30 \mathrm{~s}$; and $72^{\circ} \mathrm{C}$, $40 \mathrm{~s}$, with a final extension of $7 \mathrm{~min}$ at $72^{\circ} \mathrm{C}(24)$. The amplification products of $12 \mathrm{ml}$ were resolved on $1.5 \%$ agarose gel with a DL2000 DNA marker.

\section{Virus challenge Assay}

The LCDV and TRBIV were used to detect the CSGC cells susceptibilities to the virus. The titration value of LCDV-C and TRBIV determined based on TCID 50 assay was $10^{2} \mathrm{TCID}_{50} \mathrm{ml}^{-1}$ and $10^{3} \mathrm{TCID}_{50} \mathrm{ml}^{-1}$. $2 \times 10^{5}$ cells $\mathrm{ml}^{-1}$ was seeded into a $25-\mathrm{cm}^{2}$ flask. The infection was carried out by adding virus suspension into the cells, and one hour later, the virus solution was changed with new medium. The cytopathic effect (CPE) was observed and documented under a Nikon eclipse TE2000-U fluorescence microscope every 12 hours. The cells with and without CPE were harvested for PCR analysis and electron microscopy observation.

\section{PCR analysis and electron microscopy}

The CSGC cells DNA was extracted from the infected cells after infected with LCDV and TRBIV for $36 \mathrm{~h}$. Two pair of primers specific to the major capsid protein segment of LCDV and TRBIV (LCDVF: 5'-CCGTTGATTCCAA TGGTCA-3'; LCDVR: 5'-CACCGTCAAAGATTACAGGAG-3') (TRBIVF5' CGTGTTAAGATCCCCTCC-3'; TRBIVR 5'TCTCGTAAATGAGTGACACC-3') were employed in PCRs. The reactions were performed as the following steps: denaturation at $95^{\circ} \mathrm{C}$ for $5 \mathrm{~min}$ followed by 30 cycles of denaturation at $94^{\circ} \mathrm{C}$ for $40 \mathrm{~s}$, annealing at $57^{\circ} \mathrm{C}$ for $40 \mathrm{~s}$ and elongation at $72^{\circ} \mathrm{Cfor} 1 \mathrm{~min}$, ending with an additional elongation step of $10 \mathrm{~min}$ at $72^{\circ} \mathrm{C}$.

The CSGC cells infected with LCDV and TRBIV for $36 \mathrm{~h}$ were fixed with $2.5 \%$ glutaraldehyde in cacodylate buffer $(0.1 \mathrm{M}, \mathrm{pH} 7.4)$ for $4 \mathrm{~h}$ at $4^{\circ} \mathrm{C}$, rinsed in PBS buffer (0.1 M, pH 7.4) for 10 min with three times, then postfixed with $1 \%$ osmium tetroxide in cacodylate buffer $(0.1 \mathrm{M}, \mathrm{pH} 7.4)$ for $2 \mathrm{~h}$. After three rinses in PBS buffer $(0.1 \mathrm{M}, \mathrm{pH} 7.4)$ for $10 \mathrm{~min}$ each, the specimens were dehydrated in an ethanol series $(30 \%$, $50 \%, 70 \%, 90 \%, 100 \%, 10$ min every grade) and embedded in Epon812 epoxy resin. Ultra-thin sections were cut on a Reichert-Jung Ultracut-E microtome with a diamond knife, mounted on copper grids, stained with $2 \%$ uranyl acetate and lead citrate, and examined and photographed under a JEOL JEM-1200EX transmission electron microscope (TEM).

\section{Results}

\section{Primary culture and subculture}

A monolayer of primary cultures was obtained from the gonad of a tongue sole at 15 day after fertilization. Its serical passage led to the establishment of the cell line called CSGC, which consists of fibroblastic cells (Fig. 1). 


\section{Growth curve of CSGC cell line in different temperatures and different concentration of FBS}

When tested at passage 35 at four different temperatures, CSGC exhibited optimal growth at $24{ }^{\circ} \mathrm{C}$ and satisfactory growth at $30^{\circ} \mathrm{C}$, while no obvious cell growth was observed at $10^{\circ} \mathrm{C}$ (Fig. 2A). Thus, CSGC was maintained at $24{ }^{\circ} \mathrm{C}$ for subsequent experiments.
During the first 72 hour, CSGC cells had a great proliferation in MEM with 25\% FBS and 20\%FBS.But changes happened in the next 24 hour. Cells in MEM with $25 \%$ FBS decreased dramatically probably because the high concentration of FBS was harmful for the cells, cause the death of cells (Fig. 2B). The same effect had not found in other lower concentration of FBS.
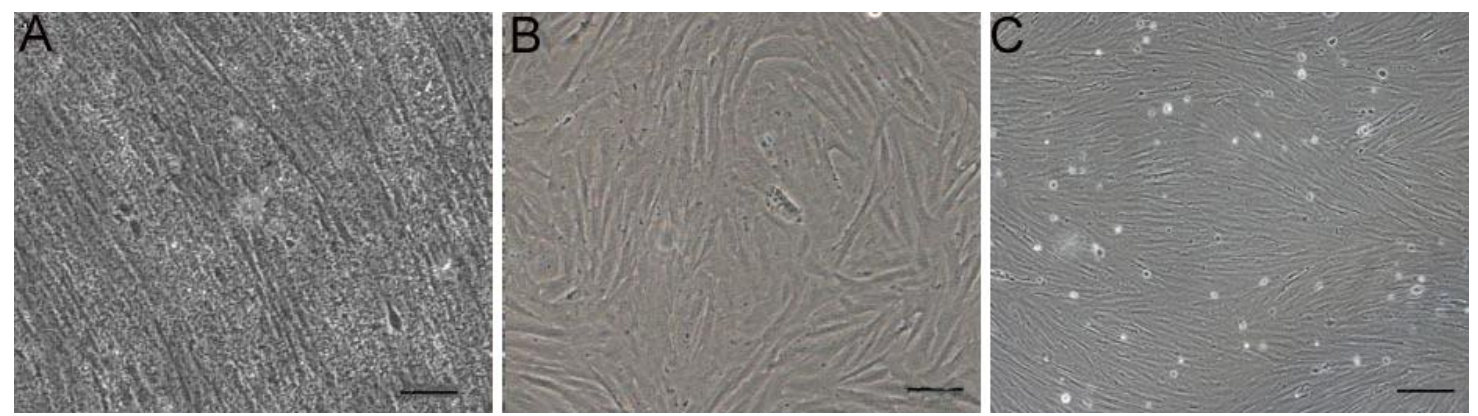

Fig. I. Cell line derivation. (A) Gonadal cells primary culture at day 5. (B) Cells at passage 3. (C) Cells at passage 40. Cells in serial culture exhibited a fibroblast-like phenotype. Scale bars, $50 \mu \mathrm{m}$ in (A and B) and $100 \mu \mathrm{m}$ in (C).

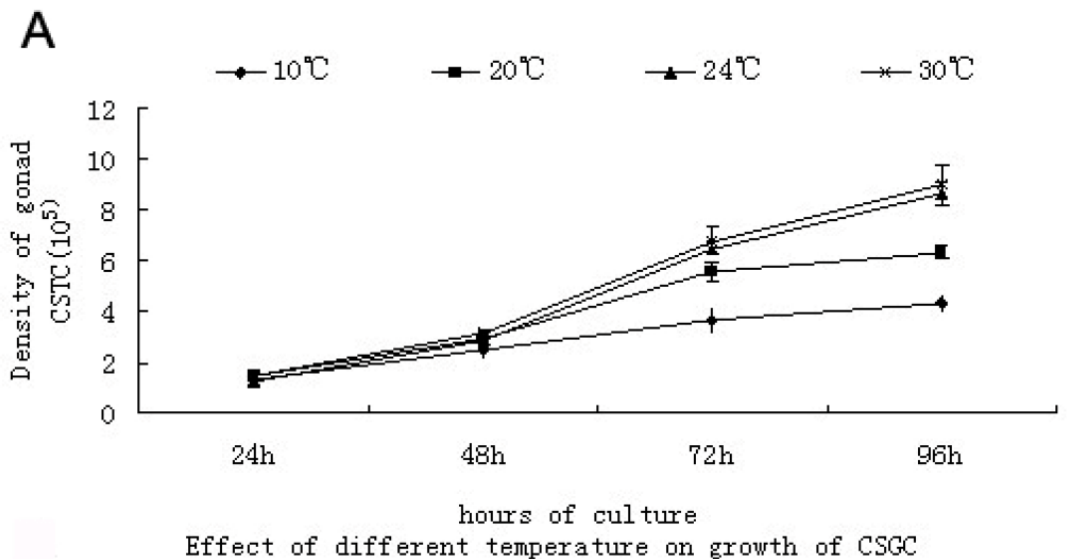

B

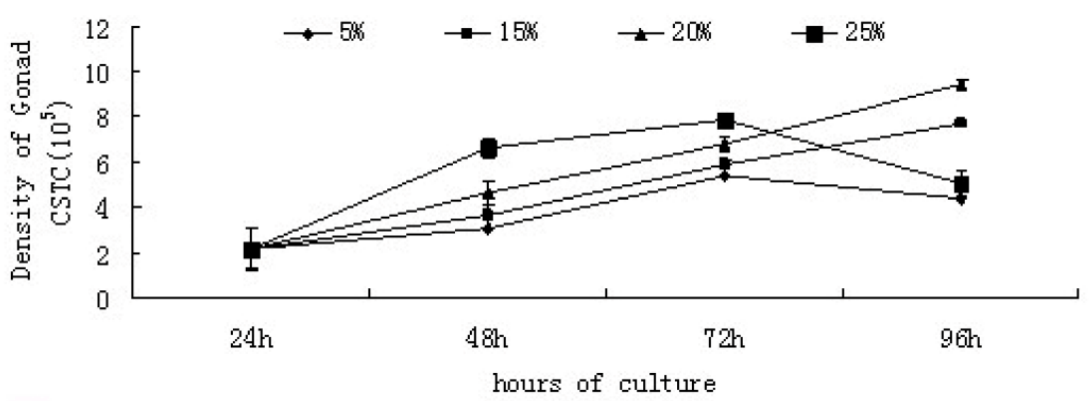

Effect of different concentration of FBS on growth of CSGC

Fig. 2. Growth requirement of CSGC cells. (A) Different temperatures. There was no obvious growth at $10^{\circ} \mathrm{C}$, and similar growth is seen at $24^{\circ} \mathrm{C}$ and $30^{\circ} \mathrm{C}$. (B) Different FBS concentration. Optimal growth is seen with $20 \% \mathrm{FBS}$. 


\section{CSGC is genetically male}

At passage 25, 35, 50, the chromosome numbers ranged from 26-60, with the majority (75\%) having 42 chromosomes of the diploid number in this organism (Fig. 3B)which meant the CSGC cells had high genetic stability. CSGC was initiated from a juvenile gonad whose sex was indeterminate. The half-smooth tongue sole shows a significant sex dimorphism, with its $\mathrm{W}$ and $\mathrm{Z}$ chromosomes being easily distinguishable. We took this advantage and examined the karyotype of the cell line. This revealed a diploid karyotype consisting of 21 pairs of chromosomes and thus a male karyotype, because the female specific $\mathrm{W}$ chromosome was absent (Fig. 3A). Furthermore, a PCR analysis revealed that a female-specific product was absent in the DNA from CSGC cells and testis, although our condition easily detected its presence in the ovary sample (Fig. 3C). Taken together, CSGC is a male cell line from a genetically male gonad, namely the testis.

\section{Detection of dmrt I expression in CSGC cells}

In several fish species such as medaka, dmrt1 is a marker of testiculat somatic cells, because it shows a preferential expression in the somatic cells but not germ cells of the testis $(25,26)$. By RT-PCR, a 352-bp specific band of the Dmrt1 gene only appeared in the testis and CSGC cells but not in the ovary and other tissues (Fig. 3D). Therefore, CSGC appears to contain somatic cells of the testis.
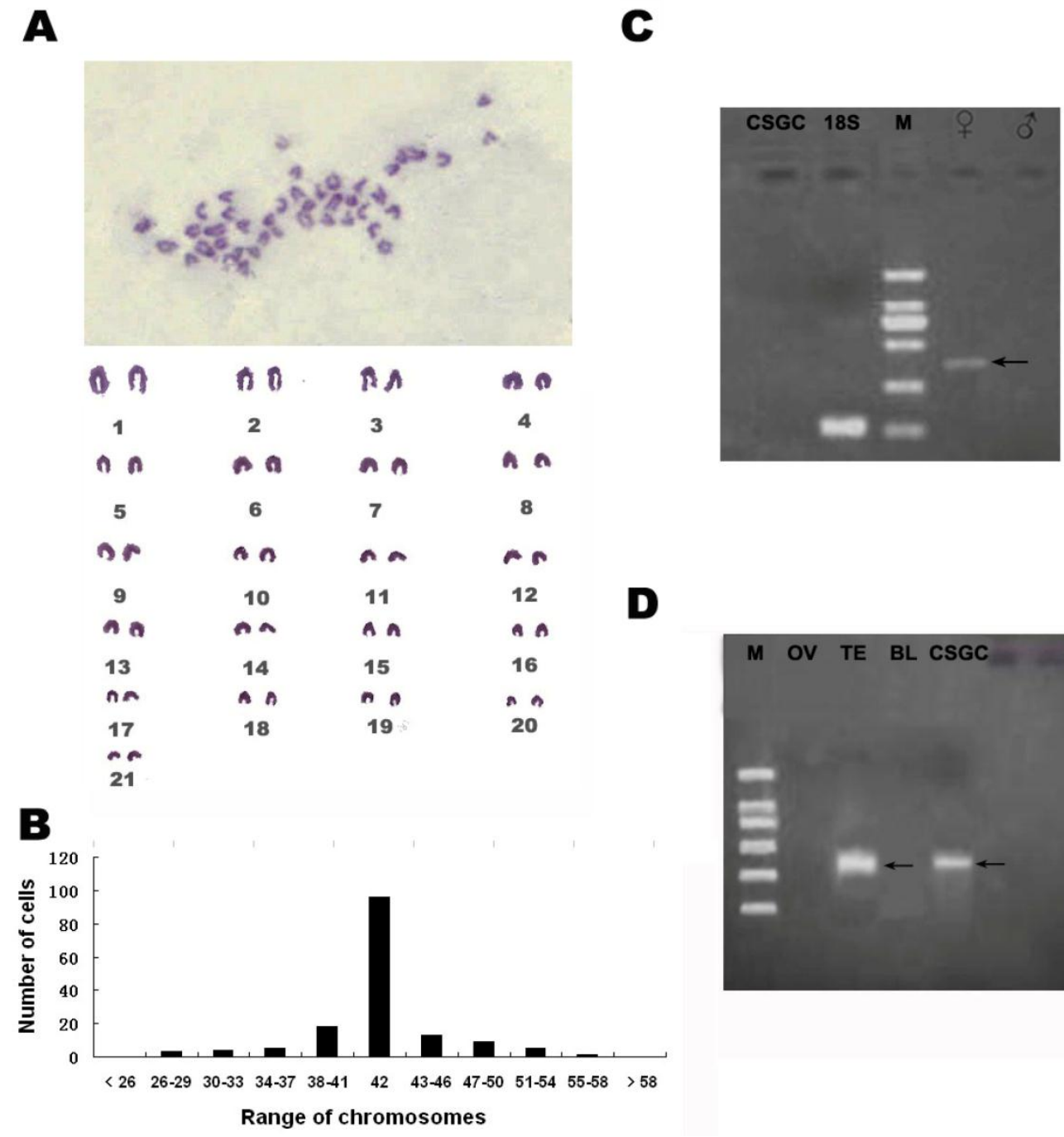

D

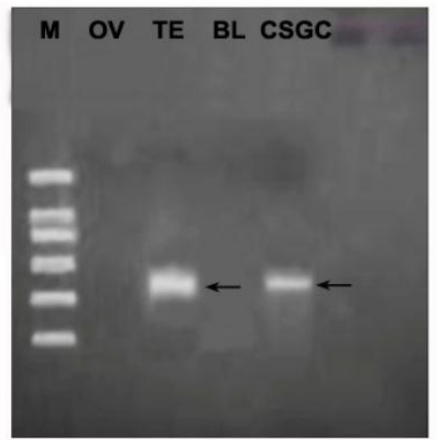

Fig. 3. Cytogenetic and molecular characterization. (A)Diploid karyotype of CSGC cells at passage 35. The female specific W chromosome is absent. (B) Chromosome number distribution. The main chromosome number was 42. (C) Absence of a female specific DNA marker. Arrow shows female control.(D) Detection of dmrtl expression. M, BM 2000 DNA marker; OV, ovary tissue; TE, Testis tissue; BL, blood. 


\section{Virus challenge assay}

The susceptibility of CSGC to two viruses, namely LCDV and TRBIV, was evaluated by CPE, PCR-analysis and Electron microscopy. Significant CPE was observed obviously in the cells in passage 45 at $36 \mathrm{~h}$ post infection with LCDV (Fig. 4B-D)and TRBIV (Fig. 4b-d). As predicted, CPE was absent in non-infected control cells (Fig. 4A, a). CPE with typical multiple vacuolation was observed in cells infected with TRBIV (Fig. 4 c) and network degeneration with stellate formation and rounding of cells seen in
LCDV infected cells (Fig. 4D). PCR assays detected a prominent product for LCDV and TRBIV (Fig. 4E).

Electron microscopic observation revealed that virus particles were scattered throughout the cytoplasm of cells infected with TRBIV and LCDV (Fig. $5 \mathrm{~A}, \mathrm{~B})$, implying that the multiplication of infected viruses in CSGC cells. The viruses were spherical to icosahedral, and measured 60 to $150 \mathrm{~nm}$ in diameter. These results demonstrate a high susceptibility of CSGC to both TRBIV and LCDV.

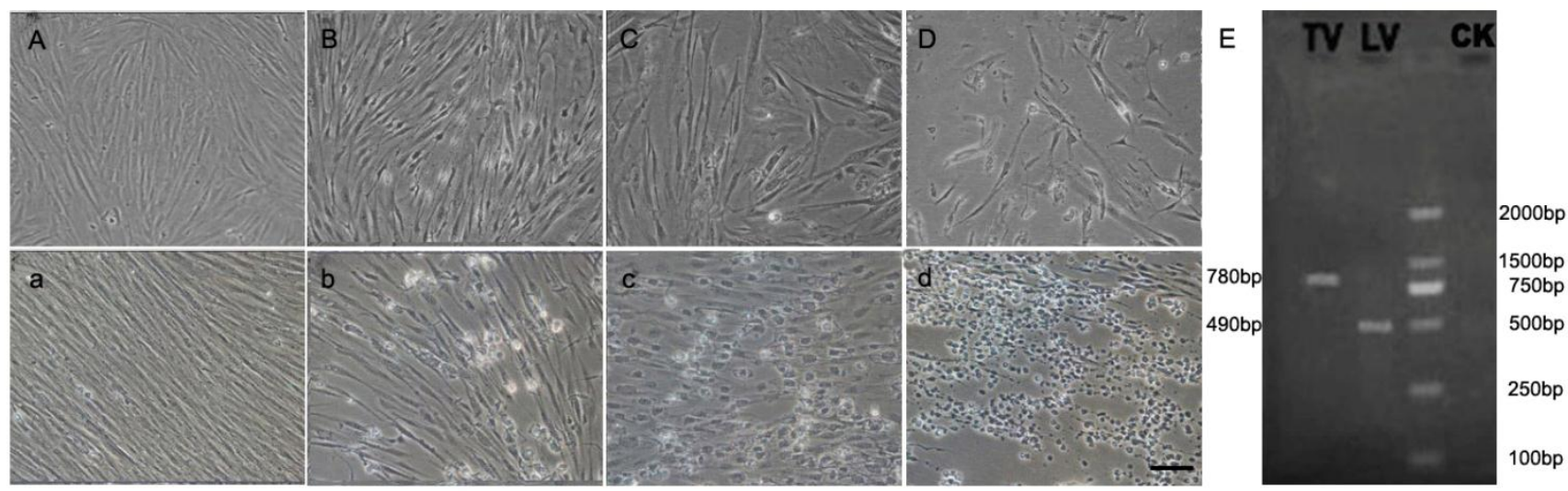

Fig. 4. CPE in CSGC cells after virus infection. CSGC cells were used passage 45. (A, a) Control cells. (B-D) Cells after infection with LCDV. (b-d) Cells after infection with TRBIV. (E) PCR-detection of viruses in infected CSGC cells.
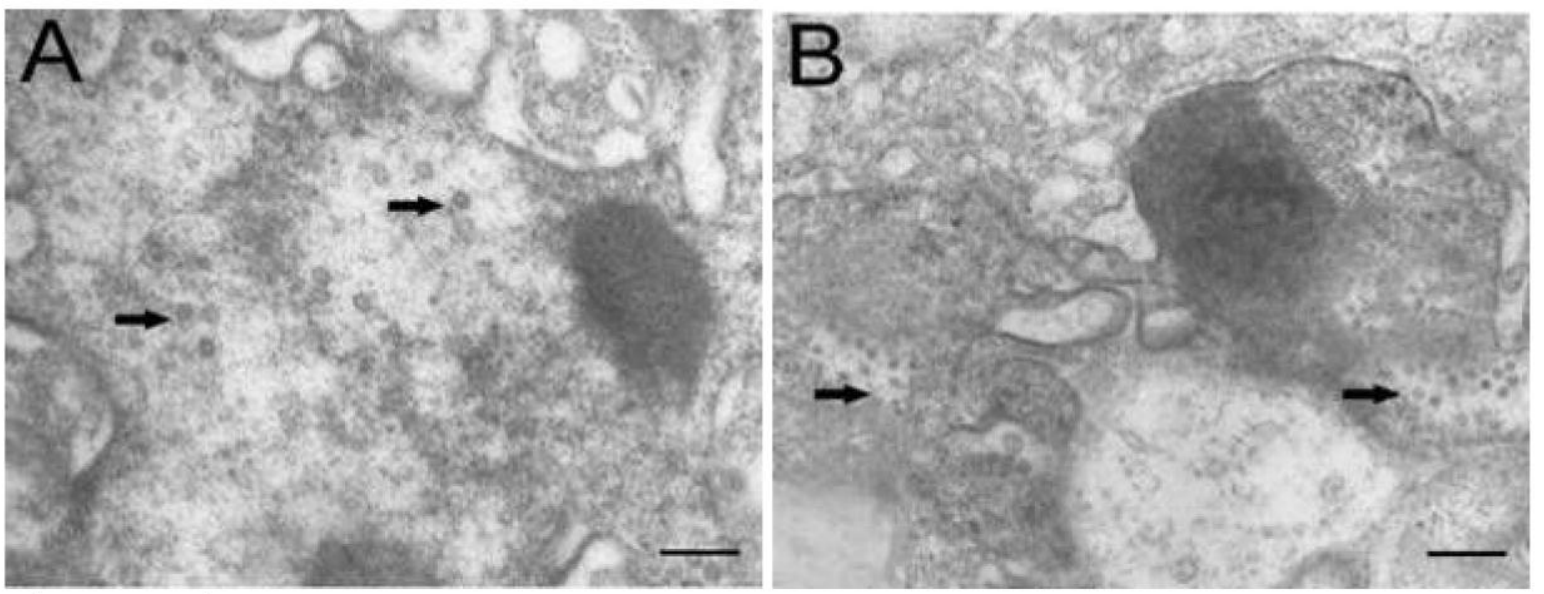

Fig. 5. Electron microscopic observation. (A) LCDV particles scattering in the cytoplasm of CSGC cells. (B) TRBIV particles scattering in the cytoplasm of CSGC cells. Magnification, 15,000×. Scale bars, 400nm in (A) and $200 \mathrm{~nm}$ in (B) 


\section{Discussion}

In this study, we have obtained a tongue sole gonad cell line designated as CSGC. Four independent lines of evidence suggest that CSGC is a testicular somatic cell line. First, CSGC has a gondal origin. Second, it lacks the heterogametic $\mathrm{W}$ chromosome and also does not contain a female specific marker, pointing to the $\mathrm{ZZ}$ genetic constitution for the maleness in this organism. Third, CSGC expresses the testicular cell marker dmrt1. Finally, CSGC cells are fibroblast-like in phenotype, compared to round or polygonal shapes of germ cells in culture (16). Although dmrt1 expression in medaka occurs preferentially in Sertoli cells $(25,26,27)$, future work is needed to determine whether CSGC essentially consists of Sertoli cells.

Since the half-smooth tongue sole is an important species for marine culture, we have tested the CSGC for potential use in studying host-pathogen interactions. We show that this cell line is highly susceptible for infection by, and propagation of, LCDV and TRBIV viruses. LCDV was firstly isolated from Japanese flounder (28) and can infect also other cell lines of marine fish species $(20,21)$. Remarkably, CSGC cell line has higher susceptibility to LCDV and TRBIV than other marine fish cell lines $(20,29,30)$. For example, typical CPE appears as early as $12 \mathrm{~h}$ post infection with LCDV and TRBIV, and dramatic propagation of both viruses in CSGC cells takes place already at $36 \mathrm{~h}$ post infection. These data suggest that CSGC can be used as a helpful tool for the isolation, proliferation and investigation of marine fish viruses.

Gonadal somatic cells are involved in differentiation of spermatogonial stem cells (sscs), which is capable of differentiation through meiosis to generate test-tube sperm and also proliferation through mitosis (17). How the gonadal somatic cells effects the spermatogonial stem cells would be a meaningful job for future research.

Sex determination has enormous diversity in fish $(31,32,33)$. The half-smooth tongue sole has the ZZ-ZW sex determination system (19). Our work in this study provides CSGC - to our knowledge - as a first testicular somatic cell line in fish. Future work will determine whether this cell line is useful to study sex -related events and interactions between male germ cells and somatic cells in culture.

\section{Acknowledgments}

This work was supported by the National Nature Science Foundation of China (31072202), the National 863 High Technology Research Foundation of China (2006AA10A401) and Taishan Scholar Project
Fund, Shandong, China.

\section{Conflict of Interests}

The authors have declared that no conflict of interest exists.

\section{References}

1. Wolf K, Quimby MC. Established eurythermic line of fish cells in vitro. Science, 1962; 135: 1065-1066.

2. Hightower LH, Renfro JL. Recent applications of fish cell culture to biomedical research. J Exp Zool, 1988; 248: 290-302.

3. Fryer JL, Lannon CN. Three decades of fish cell culture: a current listing of cell lines derived from fish. J Tiss Cult Methods, 1994; 16: 87-94.

4. Komura J, Mitani H, Shima A. Fish cell culture: establishment of two fibroblast-like cell lines (OL-17 and OL-32) from fins of the medaka, Oryzias shima. In Vitro Cell Dev Biol, 1988; 24: 294-298.

5. Watanabe T, Kobayashi N, Sato Y. Continuous cell line derived from the kidney of yamame, Oncorhynchus masou. Bull Japan Soc Sci Fish, 1978; 44: 415-418.

6. Frerichs GN, Morgan D, Hart D. Spontaneously productive Ctype retrovirus infection of fish cell lines. J Gen Virol, 1991; 72: 2537-2539.

7. Ahne W. Studies on the use of fish tissue cultures for toxicity tests in order to reduce and replace the fish tests. Zbl Bakt Hyg, Abt Orig B, 1985; 180: 480-504.

8. Chen SL, Ren GC, Sha ZX. Development and characterization of a continuous embryonic cell line from turbot (Scophthalmus maximus). Aquaculture 2005; 249: 63-68.

9. Fryer J L.Lannan C N. Three decades offish cell culture: A current listing of cell lines derived from fish. Journal of Tissue Culture Methods 1994;16: 87-94.

10. Lakra WS, Swaminathan TR, Joy KP. Development, characterization, conservation and storage of fish cell lines: a review. Fish Physiol Biochem. 2010; [Epub ahead of print].

11. Hofmann MC, Hess RA, Goldberg E. Immortalized germ cells undergo meiosis in vitro. Proc Natl Acad Sci USA, 1994, 91 : 5533-5537.

12. Feng LX, Chen Y, Dettin L. Generation and in vitro differentiation of a spermatogonial cell line. Science, 2002, 297: 392-395.

13. Miura T, Yamauchi K, Takahashi H. Hormonal induction of all stages of spermatogenesis in vitro in the male Japanese eel (Anguilla japonica). Proc Natl Acad Sci USA, 1991, 88: 5774-5778.

14. Sakai A, Tamura M, Matsumoto M. Establishment of in vitro spermatogenesis from spermatocytes in the medaka, Oryzias latipes. Dev. Growth Differ, 1997, 39: 337-344.

15. Sakai N. Transmeiotic differentiation of zebrafish germ cells into functional sperm in culture. Development 2002, 129: 3359-3365.

16. Hong YH, Liu TM, Zhao HB et al. Establishment of a normal medakafish spermatogonial cell line capable of sperm production in vitro. Proc Natl Acad Sci USA, 2004, 101: 8011-8016.

17. Barroca V, Bruno L, Mathieu C. Mouse differentiating spermatogonia can generate germinal stem cells in vivo. Nature Cell Biology, 2008, 11: 190 -196.

18. Sabine C, Markus R, Hennenlotter J. Generation of pluripotent stem cells from adult human testis. Nature, 2008, 456: 344-349.

19. Chen SL, Deng SP, Ma HY, et al. Molecular marker-assisted sex control in half-smooth tongue sole Cynoglossus semilaevis. Aquaculture, 2008; 283:7-12.

20. Wang XL, Wang N, Chen SL, et al. Establishment, characterization of a new cell line from heart of half-smooth tongue sole 
(Cynoglossus semilaevis). Fish Physio Biochem.2010; 36: 1181-1189.

21. Sha ZX, Ren GC, Wang XL, et al. Development and characterization of a cell line from the embryos of half smooth tongue sole (Cynoglossus semilaevis). Acta Oceanol Sin, 2010; 29: 81-87.

22. Earley EM. Chromosome preparations from monolayer cell culture. TCA Man, 1975; 1: 31-35.

23. Chen SL, Li J, Deng SP, et al. Isolation of female-specific AFLP markers and molecular identification of genetic sex in half-smooth tongue sole (Cynoglossus semilaevis). Mar Biotech, 2007; 9: 273-280.

24. Deng S P, Chen SL. Molecular cloning, characterization and RT-PCR expression analysis of Dmrtla from half-smooth tongue-sole, Cynoglossus semilaevis. Journal of Fishery Sciences of China, 2008; 15: 577-584.

25. Brunner B, Hornung U, Nanda I et al. Genomic organization and expression of the doublesex-related gene cluster in vertebrates and detection of putative regulatory regions for DMRT1. Genomics, 2001; 77: 8-17.

26. Sato T, Yokomizo S, Matsuda M, et al. Gene-centromere mapping of medaka sex chromosomes using triploid hybrids between Oryzias latipes and O. luzonensis. Genetica, 2001; 111:71-75.

27. Lutfalla G, Crollius HR, Brunet FG, et al. Inventing a Sex-Specific Gene: A Conserved Role of DMRT1 in Teleost Fishes Plus a Recent Duplication in the Medaka Oryzias latipes Resulted in DMY. J Mol Evol, 2003; 57:148-153.

28. Sun $X Q, Q u$ LY, Zhang JX.et al. Pathogenicity and immunogenicity of lymphocystis virus of Japanese flounder (Paralichthys olivaceus). High Technol Lett, 2000; 9:19-21.

29. Wang N, Wang XL, Sha ZX, et al. Development and characterization of a new marine fish cell line from turbot (Scophthalmus maximus). Fish Physiol Biochem, 2010;36: 1227-1234.

30. Wang XL, Chen SL, Sha ZX, et al. Establishment and Characterization of a New Cell Line from the kidney of Spotted Halibut Verasper variegates. J Ocean Univ China, 2010; 9:162-168.

31. Kondo M, Nanda I, Schmid M, et al. Sex determination and sex chromosome evolution: insights from medaka. Sex Dev. 2009; 3: 88-98.

32. Nagahama Y. Molecular mechanisms of sex determination and gonadal sex differentiation in fish. Fish Physiol Biochem, 2005; 31:105-109.

33. Sandra GE, Norma MM. Sexual determination and differentiation in teleost fish. Rev Fish Biol Fisheries, 2010; 20:101-121. 